CATHARSIS 9 (1) 2020

Halaman: 70-76

p-ISSN 2252-6900 I e-ISSN 2502-4531

UNNES

Catharsis: Journal of Arts Education

http://journal.unnes.ac.id/sju/index.php/chatarsis

\title{
Social Changes on Basisombow in The Community of Kampar Riau
} Regency

\author{
Osmawinda Putri ${ }^{\bowtie}$, Hartono Hartono, Udi Utomo \\ E-mail: Ptrwinda1@gmail.com \\ Universitas Negeri Semarang, Indonesia
}

Received 26 January 2020, Accepted 15 March 2020, Published 31 May 2020

\begin{abstract}
Basisombow is a literature that develops in the North Kampar of Kampar District. In antiquity Basisombow was used for traditional event, wedding, and circumcision event. The research aims to describe and analyze the social change of Basisombow in the community of Kampar Riau Regency. This study used qualitative research, with a sociological approach. Observation technology, interviews and documentation are used as instruments of the research in collecting the data. The data analysis procedures used data reduction, data presentation and data verification. The validity of the data in this study used Triangulation source that was performed for the inspection process by examining data from multiple sources. The results of the study that Basisombow experienced social change as follows: 1). Changes on Kampar community structure; 2). new findings and other cultural contacts; 3 ). Differences of opinion amongst generations. In particular, the findings in social change are influenced by 2 (two) factors such as; external and internal factors which are related to the social environment of the Kampar community.
\end{abstract}

Keywords: Basisombow,Social Changes, Traditional Art

DOI: https://doi.org/10.15294/catharsis.v8i4.37256 


\section{INTRODUCTION}

Culture is the whole system of ideas, actions and human mind which is learned and belonged in certain community Koentjaraningrat (2006:156).

Culture is also interpreted as knowledge of a social creature that is used to interpret the environment and its experience, as well as the foundation for its behavior (Parsudi Suparlan : 1996).

The art performing in each area in Indonesia has undergone a series of development from the performance of dance, musical, fine art, theater and drama. Its development is influenced by the supportance from the societies. Like Malay society in Riau province, they have various traditional arts which are still pereserved and developed till now. The performing art has a form and important values or norms in regulating daily life of a society.

The rules are the basic of cultures that can be changed gradually if they adapt to the development of era, but the have to give values on the existing arts with a culture speciality in the local culture (Pembudi 2015: 90).

The values and norms in a very traditional art can change the form, function, and purpose in accordance with demand of change in a society. The element of values is the most important aspect in changing the structure of mindset and attitude in a society. The changing which happens cannot be separated from the other elements which basically influence each other.

Every society will be changing constantly, both primitive and ancient society. Changes in the community is about social values, social norms, organizational behavior patterns, public institutions, power and authority, and social interactions. According to Kingsley Davis (in Soekanto 1999:259) social change is interpreted as changes that occur in the structure and function of society. Social change in a society will also be followed by cultural change.
The changes covers all aspects, from the old system to the system that can bring major changes thoroughly and essentially. Talcott Parson (Saebani 2016:113) stated that community development was related to the development of four elements of main subsystem, as follows: culture (education), Judicial (integration), Government (achievement), and economy (adaptation) which all aspect is related to each other.

Basisombow is one of the oral tradition of Malay society of Kampar in Riau province. This oral tradition is a show to convey the meaning and purpose implicitly, symbol, and usually spoken in the framework of traditional ceremony of Kampar Malay community.

Basisombow is a performance that plays an important role in the tradition of the Kampar people. One function of This art was used to express one's feelings and give a message or wish to someone other. This art is also used as a means entertainment for the public and performing on marriage to give advice to the bride and fasten brotherhood among people.

In fact, the language that is used in the Basisombow activities is understood as the expression of the message that is expressed in the form of parables, advice, poetry, and the customary allegory that is recited by a speaker will give the value of beauty in the Basisombow activity. The expression in Basisombow becomes a message for the speakers and listeners because the expression has a function socially and a meaning of philosophically for the lives of the Malay people in Kampar.

The term Basisombow/Basiacuang means to raise or flatter. Raising others means to flatter or appreciate others in communicating by being humble and unarrogant (Syarfi, et al., 2011).

Basisombow is usually used at the inauguration of male village, indigenous events and weddings to provide advice for brides and groom who will start a new life to be a family.

Basisombow was performed by the Kampar artist; Datuok Abu Bakar (61 years). The phenomenon that occurs now increasingly fewer than the interest of the public to 
appreciate Basisombow. It can be seen from his performance, Kampar teenagers consider Basisombow to be less attractive due to the modernization factor. Ball (in Andrianus et al., 2013:137) Explains the development occurs because 2 (two) processes as follows; first, the endogenous process, it is the development of the process in society itself. The second is the Exogen process, this process is caused by contact with other communities or other cultures.

From the positive side, changes occurring in the Kampar community are the changes caused by social development that are influenced by the community itself, aiming to better meet the needs of life. From the negative side, it influences on tastes that can lead to the loss of a culture, traditions, and values in the local art.

The Basisombow previously is performed at traditional ceremonies, marriages with sacred but now experienced a shift into only art performances, entertainment stage and Basisombow are regarded as customary formalities in a single event.

In the past, every traditional ceremony was deemed invalid if it is not presented with the Basiacuang. There is no traditional ceremony which is done without Basiacuang. If this is not done then the traditional ceremony will lose meaning even referred to as a violation of the indigenous of Malay Kampar. The Basiacuang is a value in every Malay community life ". (Zulfa, 43:2011).

Triyanto's research (2010) in the journal Imagination Vol. 6 No.2, discusses Kasturi, the Mayong Lor Jepara Ceramic Craftsman: A Model of Adaptailitas in the Development of Traditional Art. The results show that Kasturi's adaptability model can be used to survive in developing the traditional art business and able to adapt (adaptive) to the changing demands of the market. The key elements that determine the adaptability are positive thinking patterns, a strong need for growth, a good understanding of change and adaptation strategies in addressing change through learning and cultural modification. Then the results of research Duija (2005) in the journal Wacana Vol. 7 No.2 (111- 124), discusses Oral Traditions, Manuscripts and History. The result of his research is the oral tradition and the manuscript tradition (write) are two different traditions that are actually intertwined, but the scope of the oral tradition is broader than the manuscript tradition.

This research is based on several previous studies that have been conducted in relation to the object studied, namely the research that has been conducted, one of them was conducted by Kurnia Husmiwati (2015) who discussed the tradition of Basiacuang is an oral culture as a form of local wisdom of the Kampar Malay community and needs to be preserved in today's modernization. The tradition of Basiacuang is as one of the identity of the Kampar Malay community that contains the values and cultural norms that are still used in the wedding ceremony. The findings can be used to compare the difference and similarity of other research.

Based on the above statement, researchers are interested in discussing social change. To respond to the problem, researchers use the theory as a basis, the theory used is the social change theory of Alvin Boskoff which changes according to the view of Alvin Boskoff, there are two theories of change i.e. external and internal change theory. External theory sees that the essence of cultural change is caused by different intercultural contacts, while internal changes are caused by the encouragement of the change from the community itself.

The research aims to describe and analyze the social change of Basisombow in the community of Kampar Riau Regency. It is hoped that this research can enrich or develop science as one study of art, especially with regards to the culture contained in oral literature. This research is also expected to be able to broaden the insight and as reference material for science studies in relation to existing cultures in the local area. 


\section{METHOD}

This study used qualitative research methods and sociological approaches. The design of the research is case studies, which means the findings in this study only apply to similar characteristics and phenomena. The target of this study is social changes in Basisombow art in Kampar district.

Data collection techniques are conducted through observation, interviews and documentation. Observation was to observe the changes in the society that changed the art of Basisombow, related to the problems raised by researchers, through documentation obtained photographs, videos and documents related to changes of the art of Basisombow in Kampar district.

The validity of the data in this study used triangulation techniques, i.e. triangulation of sources means to compare and check the data that is obtained from various sources. Data analysis techniques was through the reduction stage and presented in the form of a special format according to its data properties that are possible, to then through the stage of presentation, and verification.

\section{RESULTS AND DISCUSSION}

In every culture that is inherited in society, that is can not be separated from the function of art self. Like in Basisombow, it has a function in every poem and lyrics that contain suggestions, teachings, hopes that can convey a message and good teaching for listeners. Basisombow too give a moral message, figure of speech, inspire someone stories, expressions of young people's feelings, like like, whimpering, lamenting fate, and regretting life.

The development of Basisombow's art now is identified from its function. Initially, Basisombow used as a means of emotional expression, a means of communication in association must be friendly, but now Basisombow shift function into a means the show is displayed in public
Changes in the view of Alvin Boskoff, there are two theories of change, namely the theory of external and internal changes. External theory sees that the essence of cultural change is caused by different intercultural contacts, while internal changes are caused by the encouragement of the change from the community itself.

Society is a group of people where members have communication, mutual influence. It is done by community members in the group because humans cannot live alone. The community will obey the rules and habits in which they live. (Septiana 2016:147).

\section{Kampar Community Structure Change}

Kampar is a farming city surrounded by many trees and rivers become an attraction for people outside Kampar to look for luck in farming. This make developers compete to build houses and agricultural land in Kampar. So that increase the amount of population influence traditional art in Kampar.

Increase and decrease in population influenced Basisombow from education, economics, ethnicity, and social environment. The population of Kampar district amounted to 832,387 people consisting of male population is 427,065 and female population is 405,332 . The educational factor is an increasing factor in the population in Kampar district. This can be seen from the results of the data collection of the Central Statistical Agency stating that the education indicator states that the highest level of education is S1 (undergraduate level) $57.48 \%$ and the lowest level is elementary school $0.61 \%$. Therefore, most of people have a decent education through formal learning from formal educational institutions. The consequence is changing the mindset and attitude of society, so this condition affects the appreciation of Basisombow art.

According to Soekanto (2007:275) the rapid increase of population causes a change in cultural structures in society, especially in public institutions. Kampar Regency as an agrarian city surrounded by many vegetation and rivers, became an attraction for all people 
outside the Kampar district to seek his fortune in farming. This makes the developers compete to build houses and farmland in the Kampar district so that from increasing population will affect the traditional arts in Kampar District, of course brought by new people Who is already a member of the Kampar District community.

Social change is a scientific and objective concept. Therefore, no consideration of such value is good or bad. In terms of language, the language used is already in Bahasa Indonesia and Ocu language (Kampar language), but not all people who moved to Kampar district will use their own language, they learn Local language to socialize, and communicate. It also affects the social interactions that occur in the Kampar community.

\section{Discovery And Other Cultural Contacts}

The variety modern art is in accordance with the present day and become a construction of the identity of young children. This can be understood by the artwork (music) not only serves as a media expression, but can also be a medium of identity formation, lifestyle, social class, as well as markers of character that is being constructed (Irawati in Wadiyo 2007:3).

The influence of the outside culture that is rapidly entering through various electronic media, has also influenced the interests of the younger generation who are more likely to like modern art than the art of Basisombow. In addition to the young people's view of the less attractive art of Basisombow, some young people have not had the urge to learn more deeply about the art of Basisombow, since the art of Basisombow is monotonous and the complexity of learning is also a problem for the younger generation.

The socio-cultural change in Kampar district is caused by new discoveries, and also influenced the current function of Basisombow art. Ranjabar (2015:86) suggested that a social and cultural process includes new discoveries that become the cause of change, the new cultural elements spread to other societies and the ways of new cultural element was accepted, studied, and finally used by the community itself. The statement that is stated by Ranjabar that every new discoveries that are received and learned, they will influence and lead to social culture change in society including in Kampar District.

Sophisticated communication technology makes the distance has no longer felt. Various products of technological sophistication that circulate in society become a part of main needs for each individual. In this case it is the technology that produces electronic products such as; radio, television, and mobile phones contributed to the social culture change in Indonesia. Today's technology is not only used by people in the downtown, but also used by people in rural areas. It has almost all aspects of people's lives, even farmers and common people will get the benefit. Finally, the people cannot be separated from the technology.

The occurrence of socio-cultural change due to the increasing population of Kampar district. According to Komar (in Kaplan, 2013:60) Social change is a value judgmentfree, neutral concept which does not indicate a direction but determines the new situation and the difference occurring in the society compared with the former era or situation. As stated by Sulasman and Gumilar (in Lontoh 2016:85) that society is a social system consisting of associated and integrated elements in stability.

In the socio-cultural process in Indonesia society. Surely there are people who are conscious of cultural weakness in a society. The new cultural findings are also motivated by elements of developed technology and the existence of social media that most people use.

Changes occurring in a single element of the social system will be affected from other elements. New discoveries and evolving community mindset bring the art of Basisombow to the change, the influence of the outside culture that is rapidly entering through various electronic media, can also affect the interest of the younger generation who tends to Prefer modern music to the art of Basisombow. 
Wadiyo (2006:7) that the existence of an artwork used as a means of interacting, so interactions will happen between individuals directly to the art.

It can be seen that the people play modern music in wedding event. Earlier on the wedding event was using Basisombow, but now they are moving to modern music, such as instrumental music, bands, and Dangdut because they consider Basisombow is an ancient art.

\section{Differences Of Opinion Among Generations}

The opinion of (Saebani, 2016:210) is that the factor that causes conflict is interaction or communication. Any individual, group, organization, community may experience conflicts due to interaction or communication. When communication is stuck and misunderstood, a conflict will occur. In addition, one cannot accept other people's point of view, such as religious figures who have blind fanaticism, offended personality, etc.

There is a conflict involving Basisombow, Soekanto (2006:280) stating that opposition in a society can be a cause of social and cultural change. Opposition can occur between an individual with a group or group with a group between the old Generation and young generation.

The opposition that occurred between the young generation and the old generation influenced the art of Basisombow itself because, the young generation has already voted for modern events such as modern music activities in weddings, while Older generations further advocated the art of Basisombow to advise bride and groom.

Rohidi (1994:26) says that every society always has a value system, belief system, or idea system, and other knowledge systems that are considered valuable to life together. Then the citizens assessed that the art of Basisombow needs to be preserved and handed down to the younger generation to ensure the continuity of human life or society. So if the young generation is able to play the arts and preserve it from time to time of our course as the owner of the art will not be afraid if this Basisombow art will be extinct and shifted to the development of the Times.

\section{CONCLUSION}

Basisombow has changed according to social changes because of the development of technology. The people are not interested in the art, so that the art is rarely performed. Because of the development of science and technology, Basisombow is unimportant and wordy. With the development of science and technology, Basisombow is rarely used in traditional events, circumcision events, weddings and other events. Then in ancient times the Basisombow show has unlimited duration. Due to the duration of Basisombow is too long, so it is already very rare. This factor makes Basisombow go to the extinction. Another thing that causes Basisombow extinct is its successor generation, because the Basisombow speakers are the adult men. To maintain the Basisombow tends to be difficult because of age problems.

\section{ACKNOWLEDGEMENT}

A huge appreciation to Dr. Hartono, M. Pd. and Dr. Udi Utomo, M.Si. Who have guided and directed the author in completing this study. The author also would like to thank the informant of this study which has conveyed information on social changes of Basisombow in the community of Kampar Riau Regency.

\section{REFERENCE}

Adrianus, Sri Iswidayati, Triyanto. 2016. Patung Pantak Dayak Kanayatn: Kajian Bentuk Dan Fungsi Dalam Perubahan Sosial Budaya. Catharsis: Journal of Arts Education, 5 (2), 135141. Semarang: Pendidikan Seni Pascasarjana UNNES..

Desti Kumala Sari, Wadiyo, Sunarto. 2018. Pengaruh Perubahan Sosial Budaya terhadap Bentuk Seni Randai Kuantan 
di Kuantan Singingi Riau. Catharsis : Journal of Arts Education, 7 (1) 86-92

Duija. 2005. "Tradisi, Naskah dan Sejarah". Jurnal Wacana Vol. 7 No. 2 (111-124)

Kaplan, Y1lmaz., Demet Tekinay, Alkan Uğurlu. 2013. "Social Change and Sport: A Sociological Evaluation". International Journal of Science Culture and Sport, 1(4): 59-63

Lontoh, W., Wadiyo, \& Udi Utomo. (2016). Syarofal Anam: Fungsionalisme Struktural pada Sanggar Annajjam Kota Palembang. Catharsis: Journal of Arts Education, 5(2), 84-90.

Pambudi, Sri Isdawati, Teguh Supriyanto. (2015). Perkembangan Bentuk Topeng Barongan Dalam Ritual Murwakala Di Kabupaten Blora. Jurnal Catharsis: Journal of Arts Semarang: Pendidikan Seni Pascasarjana UNNES.

Reza Nepilia Sari, Udi Utomo. 2018. Perubahan Fungsi Seni Rejung di Kota Pagaralam. Catharsis : Journal of Arts Education, 7 (1) 109-116

Rohidi, R, T. 1994.pendekatan Sistem Sosial Budaya Dalam Pendidikan. Semarang: IKIP Semarang Press.

Sebani, Ahmad. 2016. Perspektif Perubahan Sosial. Bandung: CV Pustaka Setia

Sepiana, Totok sumaryanto, Agus Cahyano. 2016. Nilai Budaya Pertunjukan Musik
Terbangan pada Masyarakat Semende. Jurnal Catharsis: Journal of Arts Education. No 5 (2) (2016). Semarang: Pendidikan Seni Pascasarjana UNNES

Soekanto, S. 1999. Sosiologi: Suatu Pengantar (Edisi Baru Keempat 1990). Jakarta: PT. Raja Grafindo Persada

Soekanto, S. 2006. "Sosiologi Suatu Pengantar. Jakarta Utara : PT Raja Grafindo Persada.

Soekanto, S. 2007. Sosiologi Suaru Pengantar. Jakarta: Raja Grafindo Persada

Suparlan, Parsudi 1995. Kemiskinan di Perkotaan. Jakarta: Yayasan Obor Indonesia

Syarfi. (2011). Siacuong (Sisombau) dalam Masyarakat Adat Kampar. Pemerintah Kabupaten Kampar: Dinas Pariwisata dan Kebudayaan Kabupaten Kampar

Triyanto. 2009. "Kasturi: Sebuah Model Adaptabilitas dalam Pengembangan Seni Tradisi". Semarang: Universitas Negeri Semarang

Wadiyo. (2006). Seni sebagai Interaksi Sosial. Jurnal Harmonia: Jurnal Pengetahuan Dan Pemikiran Seni, 7(2).

Zulfa. (2012). Tradisi Basiacuang pada Masyarakat Melayu Kampar-Riau. Jakarta. Universitas Indonesia 